\title{
ANTITESTICULAR EFFECT OF METALLIC AND RARE EARTH SALTS
}

\author{
V. P. KAMBOJ AND AMIYA B. KAR \\ Central Drug Research Institute, Lucknow, India
}

(Received 11th Fune 1963)

\begin{abstract}
Summary. The effect on the testis of some forty-two water-soluble salts of metals and rare earths was investigated in rats and mice. In general, a single intratesticular injection caused varying degrees of degeneration of the seminiferous epithelium and the interstitium. Thirty-five of the salts tested exerted some degree of antitesticular effect. A single subcutaneous injection was ineffective but continuous administration by the same route caused selective spermatogenic arrest with nine salts. Some of the salts caused aspermia of the recipient animals; others disintegrated the residual spermatozoa in the ductus deferens by separation of the head and tail. The possible mechanism of action of the salts is discussed.
\end{abstract}

\section{INTRODUCTION}

Several metallic salts have been reported to evoke alterations in the mammalian testis. Thus, Macleod, Swan \& Aitken (1949) observed that lithium chloride stimulates aerobic lactic acid production in the rat testis. Adverse effects on the testis and reproduction have been recorded after administration of iron, molybdenum, thallium and lead salts (Heffter \& Heuber, 1935; Hamilton \& Hardy, 1949; Jeter \& Davis, 1954; Telkka, Kuusisto \& Antila, 1956). The important role of zinc in spermatogenesis is now well documented (Elcoate, Fischer, Mawson \& Miller, 1955; and others). Trace amounts of magnesium, aluminium, titanium, vanadium, nickel, strontium and bismuth have been detected in the testis (Heffter \& Heuber, 1935; Takoaka, 1954). Considerable interest has been created by the recent observation that a single subcutaneous or intratesticular injection or simple scrotal inunction of cadmium salts causes acute destruction of the seminiferous epithelium in several mammalian species including goats and rhesus monkeys (Pařizek, 1960; Kar \& Das, 1960, 1962 a, b; Kar, 1961, 1962; Kar \& Kamboj, 1963). The interstitial elements, however, regenerate and become functional after an initial phase of atrophy. These effects can be prevented by concurrent administration of zinc or selenium salts which per se do not influence the testis (Pařizek, 1960; Kar, Das \& Mukerji, 1960).

A systematic study of the effects of metallic and rare earth salts on the testis of rats and mice has been undertaken, and this paper presents a preliminary account of the results. 


\section{MATERIALS AND METHODS}

Colony-bred adult albino rats and mice (Swiss strain) of the Institute weighing 100 to $120 \mathrm{~g}$ and 20 to $30 \mathrm{~g}$, respectively, were used in this investigation. All the animals were maintained under uniform laboratory conditions throughout the experimental period.

\section{TABLE 1}

TESTIS WEIGHT AFTER INTRATESTIGULAR INJECTION OF SALTS

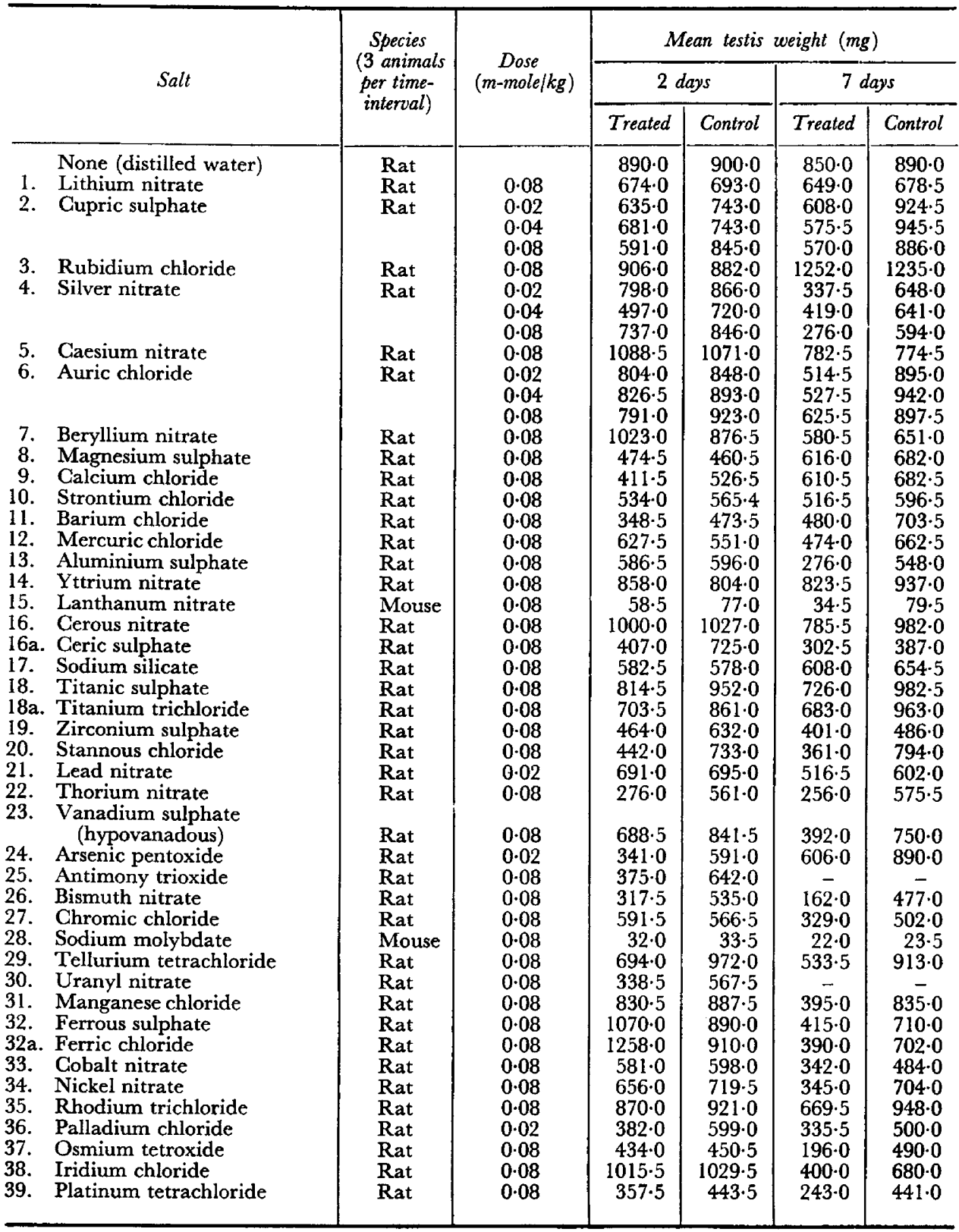


To facilitate administration, only water-soluble salts were used. They were injected by the subcutaneous or intratesticular routes. In the latter procedure a salt was injected into the left testis, the right one serving as a control and receiving sterile distilled water alone in a similar manner. A single injection was the routine in rats irrespective of the route, but in mice (except that lanthanum

TABLE 2

TESTIS WEIGHT AFTER SUBCUTANEOUS INJECTION OF SALTS

\begin{tabular}{|c|c|c|c|c|c|}
\hline \multirow{2}{*}{ Salt } & \multirow{2}{*}{ Species } & \multirow{2}{*}{$\begin{array}{c}\text { Dose } \dagger \\
(m-m o l e / k g)\end{array}$} & \multicolumn{3}{|c|}{ Mean testis weight (mg) } \\
\hline & & & 2 days & 7 days & 30 days \\
\hline $\begin{array}{l}\text { None (distilled water)* } \\
\text { None (distilled water)* }\end{array}$ & $\begin{array}{l}\text { Mouse } \\
\text { Rat }\end{array}$ & 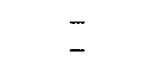 & $\begin{array}{l}103 \cdot 0 \\
950 \cdot 0\end{array}$ & $\begin{array}{l}110 \cdot 0 \\
880 \cdot 0\end{array}$ & $\begin{array}{l}105 \cdot 0 \\
900 \cdot 0\end{array}$ \\
\hline 2. Cupric sulphate & & 0.08 & $720 \cdot 0$ & $750 \cdot 0$ & - \\
\hline & Mouse & 0.08 & - & - & $32 \cdot 0$ \\
\hline 4. Silver nitrate & Rat & 0.08 & $621 \cdot 0$ & $763 \cdot 0$ & $5 \overline{50}$ \\
\hline 6. Auric chloride & Rat & $\begin{array}{l}0.08 \\
0.08\end{array}$ & $551 \cdot 5$ & $620 \cdot 0$ & $23 \cdot 0$ \\
\hline & Mouse & 0.08 & - & - & $65 \cdot 0$ \\
\hline 12. Mercuric chloride & Rat & 0.02 & - & $568 \cdot 0$ & - \\
\hline 13. Aluminium sulphate & $\begin{array}{l}\text { Mouse } \\
\text { Mouse }\end{array}$ & $\begin{array}{l}0.02 \\
0.08\end{array}$ & - & - & $\begin{array}{l}50 \cdot 4 \\
31 \cdot 6\end{array}$ \\
\hline 15. Lanthanum nitrate & Rat & 0.08 & - & $602 \cdot 5$ & \\
\hline & Mouse & 0.08 & - & - & $20 \cdot 6$ \\
\hline $\begin{array}{l}\text { 17. Sodium silicate } \\
\text { 20. Stannous chloride }\end{array}$ & Rat & 0.08 & - & $624 \cdot 0$ & - \\
\hline $\begin{array}{l}\text { 20. Stannous chloride } \\
\text { 21. Lead nitrate }\end{array}$ & $\begin{array}{l}\text { Mouse } \\
\text { Rat }\end{array}$ & $\begin{array}{l}0.08 \\
0.02\end{array}$ & $\begin{array}{c}98 \cdot 0 \\
-\end{array}$ & $\begin{array}{r}86 \cdot 0 \\
880 \cdot 0\end{array}$ & - \\
\hline & Mouse & 0.02 & - & - & $37 \cdot 4$ \\
\hline $\begin{array}{l}\text { 22. Thorium nitrate } \\
\text { 23. Vanadium sulphate }\end{array}$ & Rat & 0.08 & - & $620 \cdot 0$ & - \\
\hline (hypovanadous) & Mouse & 0.08 & $90 \cdot 0$ & $94 \cdot 0$ & $45 \cdot 0$ \\
\hline 24. Arsenic pentoxide & Mouse & 0.02 & $65 \cdot 5$ & $100 \cdot 0$ & $70 \cdot 0$ \\
\hline 26. Bismuth nitrate & Mouse & 0.08 & - & - & $23 \cdot 0$ \\
\hline 27. Chromic chloride & Mouse & 0.08 & - & - & $27 \cdot 0$ \\
\hline 31. Manganese chloride & Mouse & 0.08 & $78 \cdot 5$ & $80 \cdot 0$ & - \\
\hline 33. Cobalt nitrate & Mouse & 0.08 & $75 \cdot 0$ & $68 \cdot 0$ & - \\
\hline 34. Nickel nitrate & Mouse & 0.08 & $75 \cdot 0$ & $78 \cdot 0$ & $70 \cdot 0$ \\
\hline 36. Palladium chloride & Mouse & 0.02 & 1070 & - & $73 \cdot 0$ \\
\hline 37. Osmium tetroxide & Mouse & 0.08 & $107 \cdot 0$ & $104 \cdot 0$ & $30 \cdot 0$ \\
\hline 39. Platinum tetrachloride & Mouse & 0.08 & & & 49.0 \\
\hline
\end{tabular}

* Six animals per time interval; three in all other cases.

$\dagger$ Total dose in mice.

nitrate and sodium molybdate were injected intratesticularly) the total dose calculated on a body weight basis was administered subcutaneously in thirty daily doses (Table 2). The volume of solution was, however, kept constant $(0.2 \mathrm{ml})$ throughout. The dosage and route of administration are detailed in Tables 1 and 2.

The animals were killed 2, 7 and 30 days after injection (Tables 1 and 2). The testes were dissected out and weighed to the nearest $0.1 \mathrm{mg}$ on a Roller-Smith balance. For histological study, the testes were fixed in Bouin's fluid and serial paraffin sections were stained with Ehrlich's haematoxylin and eosin. Spermatozoa were collected from the middle segment of the ductus deferens for microscopical examination. 


\section{RESULTS}

\section{Morphology}

EFFECT OF INTRATESTICULAR INJEGTION

Most of the salts reduced the weight of the testis at some stage or other, the exceptions being Salts 1, 3, 5, 8, 9 and 10 (Table 1). The macroscopic features of the testis after injection varied from normal or apparently normal to total necrosis (Table 3 ). The morphology of the contralateral testis receiving distilled water alone was normal as a rule. Of the salts which did not evoke any morphological change, Nos. 3, 5, 8, 9, 10, 17 and 28 did not alter the histology either. In general, the morphology of the testis bore no direct relationship to the nature and extent of histological change caused by a salt.

TABLE 3

TESTICULAR NECROSIS AFTER SALT ADMINISTRATION

\begin{tabular}{|c|c|c|c|}
\hline \multirow{2}{*}{\multicolumn{2}{|c|}{ Condition of testis }} & \multicolumn{2}{|c|}{ Salts* } \\
\hline & & 2 days & 7 days \\
\hline 0 & $\begin{array}{l}\text { Normal or } \\
\text { apparently normal }\end{array}$ & $\begin{array}{l}1,3,5,8,9,10,11,17 \\
28\end{array}$ & $\begin{array}{l}1,3,5,8,9,10,11,17 \\
28,33\end{array}$ \\
\hline+ & Focally necrosed & $\begin{array}{l}2,4,6,12,13,15,16 \\
21,31,34,37,38\end{array}$ & 31,34 \\
\hline++ & Partially necrosed & $7,14,16 \mathrm{a}, 32,32 \mathrm{a}$ & $2,4,6,12,13,16,21$ \\
\hline++ & Totally necrosed & $\begin{array}{l}2,4,6,18,18 a, 19,20 \\
22,23,24,25,26,27, \\
29,30,35,36,39\end{array}$ & $\begin{array}{l}2,4,6,7,14,15,16 a, \\
18,18 \mathrm{a}, 19,20,22,23, \\
24,25,26,27,29,30, \\
32,32 \mathrm{a}, 35,36,37,38, \\
39\end{array}$ \\
\hline
\end{tabular}

* The number refers to the name of the salt in Table 1 ; when a number appears more than once under the same time interval it indicates dose effect.

\section{Histology}

The majority of the salts (Nos. 2, 6, 14, 16, 18, 19, 22, 23, 25, 27, 30, 32, 32a, 34 and 38) caused severe damage to the seminiferous epithelium with exfoliation and lysis of the cellular elements. Some of the tubules were replaced by a debris (PI. 1, Fig. 6). The tunica propria showed varying degrees of disintegration. Multinucleate spermatids were common. The interstitium was markedly disorganized with oedema, vascular enlargement, frequent thrombus formation and destruction of the Leydig cells. Inflammatory changes were also seen in the interstitium in many cases. Thorium nitrate (No. 22) caused perhaps the most severe damage to the testis which was converted to a mere haemorrhagic mass, with the outline of only a few tubules barely discernible (Pl. 2, Fig. 7). A unique change was produced by nickel nitrate (No. 34) which caused extensive haemorrhage throughout the interstitium without mass destruction of the Leydig cells at 2 days (Pl. 2, Fig. 9) but by 7 days it had reverted to normal.

At 7 days while the tubular damage caused by the salts persisted as a rule, there were some indications of regeneration of the interstitium (Salts 2, 4, 6, 7, 
$12,14,15,27,31$ and 34). This was evident from the proliferation of fibroblasts from underneath a thickened tunica albuginea into the intertubular spaces and formation of new blood vessels (Pl. 2, Fig. 8). However, healthy Leydig cells were rare. A slight deviation from this general pattern was seen with Salts 1, 11 and 33 which caused mild disorganization of the seminiferous epithelium and the interstitium at 2 days, but at 7 days the histological picture became normal (Pl. 1, Fig. 3). Similarly, Salts 24 and 35 destroyed the interstitium more promptly than the seminiferous epithelium (Pl. 1, Fig. 5). The histology of the contralateral testis injected with distilled water alone was consistently normal (Pl. 1, Fig. 1).

\section{Spermatozoa}

Of the total number of salts examined twenty (Salts 1, 3, 5, 8 to $11,17,18$, 19 to $21,23,28$ to $31,33,34$ and 38) had no effect on the residual spermatozoa in the ductus deferens. Salts 22, 24, 25, 27, 36 and 39 destroyed all the spermatozoa within 2 days but others (Salts 2, 4, 7, 12 to 15, 26, 32a and 37) did not do so until a few days later. Perhaps the most interesting effect was that of Salts $16,16 \mathrm{a}, 18$ and 35 which caused a disintegration of the spermatozoa by separation of the head and tail, the last two salts were more potent because they affected about $70 \%$ of the spermatozoa in this manner (Pl. 2, Figs. 10,11 and 12).

\section{Morphology}

\section{EFFECT OF SUBCUTANEOUS INJECTION}

A single subcutaneous injection had no effect on the weight of the testis in rats but daily administration (Salts 2, 4, 6, 12, 13, 15, 21, 26 to 28, 33, 34, 36, 37 and 39 ) reduced the weight in mice in varying degrees (Table 2). No necrotic changes were seen in the testis.

\section{Histology}

A single subcutaneous injection did not alter the histology of the rat testis. Daily administration by the same route to mice caused shrinkage of the tubules and spermatogenic arrest at the primary spermatocyte or spermatogonial stages (Pl. 1, Fig. 4) without affecting the interstitium (Salts 4, 13, 15, 26, 27, $30,34,37$ and 39). Distilled water alone had no effect on the histology of the testis (Pl. 1, Fig. 2).

\section{Spermatozoa}

A single subcutaneous injection was without any effect on the residual spermatozoa in the ductus deferens of rats. Similar examination of spermatozoa was not done in mice after daily subcutaneous administration of the salts.

\section{DISCUSSION}

The results of the present study show that metallic and rare earth salts evoke several types of changes in the rodent testis. All of these changes were, however, of a pathological nature and involved the seminiferous tubules and the interstitium. In contrast to cadmium chloride (Kar \& Das, 1960; Pařízek, 1960), 
none of the salts proved effective by a single subcutaneous injection at least during the test period employed in this study. Even the specificity of the antispermatogenic effect of some of the salts in mice was not quite so marked because unlike cadmium chloride, they had to be injected daily by the subcutaneous route for 30 days to elicit this effect.

A close scrutiny of the histological findings following intratesticular injection of the salts reveals certain interesting details. Thus, all of the effective salts caused varying degrees of damage both to the seminiferous tubules and the interstitium, none exerted a strictly selective influence on either component of the testis. Moreover, the two components were not damaged with equal pace by some of the salts. However, caution must be exercised in interpreting the variable responses of the interstitium on this ground, because the extent of permeation of a salt when injected intratesticularly, and the actual site of injection in relation to the blood supply of the organ may be more critical in determining the nature of interstitial changes.

Most of the salts effective by the intratesticular route caused permanent damage to the seminiferous epithelium because all of the elements including spermatogonia were destroyed. However, the effect of a few salts was relatively mild and did not extend beyond exfoliation and spermatogenic arrest. It was possible that such effects were reversible. Similarly, it was not unlikely that all the subcutaneous effective salts caused reversible interruption of spermatogenesis in mice. In contrast, the damage to the interstitium after intratesticular injection seemed mostly acute and reversible, because at 7 days there were indications of recovery as shown by the remission of vascular and inflammatory changes and repopulation with fibroblasts proliferated from the tunica albuginea.

Apart from the testis itself, the salts somehow influenced the residual spermatozoa in the ductus deferens. The most interesting effect was a disintegration of the spermatozoa by separation of the head and tail. Kar \& Das (1962b) observed a similar effect of cadmium chloride on rat spermatozoa after a single subcutaneous or intratesticular injection. Earlier, White (1955) reported the same type of effect with several heavy metallic salts on human spermatozoa in vitro. In the present study, many salts were also found to cause aspermia by destruction of spermatozoa in the ductus deferens. Some salts acted on the spermatozoa promptly within 2 days but others did not do so until a few days later. It would appear that such an in-vivo spermicidal effect in the ductus deferens was due primarily to the introduction of these salts directly into the testis. It is conceivable that a salt actually spread to the ductus deferens from the testis via venous or lymphatic circulation to affect the spermatozoa. The ineffective salts were either intrinsically non-toxic to the spermatozoa or did not attain the spermicidial concentration in the ductus deferens.

The damage to the testis after intratesticular injection of different salts was clearly of a generalized nature characterized by ischaemia, inflammation and cytolysis. Metallic ions have been known to disturb cell physiology and metabolism by more than one mechanism (Passow, Rothstein \& Clarkson, 1961). Most of them form complexes with ligands containing sulphur, nitrogen, or oxygen as electron donors. The formation of complexes with these ligands which are integral parts of amino acids, proteins and almost all other molecules of 
biological significance has been reported to lead to severe derangement of the metabolism of a cell and eventually its death (Edsall \& Wyman, 1958). Perhaps the most vital cellular constituents affected by the metals are the enzyme systems which are concerned with virtually every aspect of cellular activity. The toxic influence of the metals is known to be directed against all the factors necessary for the optimal activity of an enzyme like the enzyme molecule itself, its substrate, the cofactors and the activators (Passow et al., 1961). The binding of metals to any one of these factors may disturb the overall activity of an enzyme vis-à-vis cellular metabolism. Both the endocellular enzyme systems and those located on the cell surface are affected equally by the metals. The latter enzymes play an important role in splitting non-penetrating substances into substrates which can pass the cell membrane and reach their endocellular partners (Rothstein, 1959).

The metals also evoke specific alterations in the permeability of the cell membrane and the associated transmembrane potentials. The other important effect on the cell membrane is the inhibition of ion-transporting systems and the resultant disturbance in fluid movements (Rothstein, 1959). All of these effects combined together are believed to constitute a molecular stress on the cell membrane; when the stress reaches a threshold level for a given cell a generalized breakdown of the membrane results with the release of cellular constituents (Rothstein, 1959). From the acuteness and severity of damage to the testis after direct infusion, it is possible that the salts acted primarily on the cell membrane causing its dissolution and eventually on the intracellular constituents to convert them into a debris. The ischaemia perhaps added to the severity of such local cellular effects of the salts. However, the relatively mild effect of the subcutaneous injected salts on the spermatogenic epithelium of mice may be due to a disturbance in pituitary gonadotrophic activity.

\section{AGKNOWLEDGMENTS}

This investigation was supported by a grant from the Population Council, Inc, New York. The authors are grateful to Dr M. L. Dhar for his interest in this study. Thanks are due to Messrs R. P. Sinha and K. Narain for technical assistance and $\mathrm{Mr} \mathrm{S}$. Banerjee for the illustrations.

\section{REFERENCES}

Edsall, J. T. \& Wyman, J. (1958) Biophysical chemistry, Vol. I. Academic Press, New York.

Elcoate, P. V., Fischer, M. I., Mawson, C. A. \& Miller, M. J. (1955) The effect of zinc deficiency on the male genital system. F. Physiol. 129, 53.

Hamirton, A. \& Hardy, H. L. (1949) Industrial toxicology. Hoeber, New York.

Heffter, A. \& Heuber, W. (1935) Handbuch der Experimentellen Pharmakologie, Vol. 3. Springer, Berlin. Jeter, A. M. \& Davis, G. K. (1954) The effect of dietary molybdenum upon growth, hemoglobin, reproduction and lactation of rats. 7. Nutr. 54, 215.

KAR, A. B. (1961) Chemical sterilization of male rhesus monkeys. Endocrinology, 69, 1116.

KAR, A. B. (1962) Chemical sterilization of male goats. Ind. F. vet. Sci. 32, 70.

KAR, A. B. \& DAs, R. P. (1960) Testicular changes in rats after treatment with cadmium chloride. Acta biol. med. germ. $5,153$.

KAR, A. B. \& DAs, R. P. (1962a) Sterilization of males by intratesticular administration of cadmium chloride. Acta endocr. 40, 381.

KAR, A. B. \& DAs, R. P. (1962b) Effect of cadmium chloride on fertility of rats. Ind. J. vet. Sci. 32, 210. 
Kar, A. B., DAs, R. P. \& MukerJI, B. (1960) Prevention of cadmium induced changes in gonads of rats by zinc and selenium-a study in antagonism between metals in biological system. Proc. nat. Inst. Sci. India, 26, 40.

Kar, A. B. \& KamboJ, V. P. (1963) Sterilization of males by scrotal inunction of cadmium chloride. 7. Reprod. Fertil. 5, 461.

Macleod, J., Swan, R. G. \& Artken, G. A., JR. (1949) Lithium: its effect on human spermatozoa, rat testicular tissue, and on rats in vivo. Amer. . Physiol. 157, 177.

PAřizeK, J. (1960) Sterilization of males by cadmium salts. $\mathcal{F}$. Reprod. Fertil. 1, 294.

Passow, H., Rothstein, A. \& Clarkson, T. W. (1961) The general pharmacology of the heavy metals. Pharmacol. Rev. 13, 185.

Rothstein, A. (1959) Gell membrane as site of action of heavy metals. Fed. Proc. 18, 1026.

TAKAOKA, K. (1954) Inorganic elements in endocrine organs and their significance. Folia endocrin. Fap. 30, 499.

Telkka, A., Kuusisto, A. N. \& Antila, V. (1956) Effect of continued iron administration on the endocrine glands of the guinea-pig. Ann. Med. exp. Fenn. 34, 259.

White, I. G. (1955) The toxicity of heavy metals to mammalian spermatozoa. Aust. J. exp. Biol. med. Sci. 33, 359.

\section{EXPLANATION OF PLATES}

\section{PLATE 1}

Fig. 1. Rat testis injected with distilled water intratesticularly. Typical features. $\times 170$. Fig. 2. Testis of a mouse injected with distilled water subcutaneously. Typical features. $\times 170$.

Fig. 3. Testis of a rat injected with cobalt nitrate intratesticularly. Note mild degeneration of the seminiferous epithelium and the interstitium. Similar conditions were seen with Salts 1 and $11 . \times 170$.

Fig. 4. Testis of a mouse injected with uranyl nitrate subcutaneously. Note shrinkage of the tubules and spermatogenic arrest. Interstitium was normal. Similar conditions were seen with Salts 4, 13, 15, 26, 27, 34, 37 and 39. $\times 170$.

Fig. 5. Testis of a rat injected with palladium chloride intratesticularly. Note earlier destruction of the interstitium. Salt 24 had similar effects. $\times 170$.

Fig. 6. Testis of a rat injected with $0.08 \mathrm{~m}$-mole/kg copper sulphate intratesticularly. Note severe damage to the tubules and the interstitium. Such effects were noted with Salts $6,14,16,18,19,22,23,25,27,30,32,32 \mathrm{a}, 35$ and 38 . $\times 170$.

\section{PLATE 2}

FIG. 7. Testis of a rat injected with thorium nitrate intratesticularly. Note severe degeneration of the testis. The entire organ was invaded by fibroblasts and leucocytes and was beyond recognition except for a few degenerated tubules as in this Fig. $\times 170$.

Frg. 8. Testis of a rat injected with aluminium sulphate intratesticularly. The tubules were totally destroyed but there is regeneration of the interstitium in so far as its fibroblastic content is concerned. Other salts which had similar effects were Nos. 2, 4, 6, 7, 12, 14, 15, 27 and $31 . \times 170$.

Frg. 9. Testis of a rat injected with nickel nitrate intratesticularly. Note peculiar interstitial haemorrhage. $\times 170$.

FIg. 10. Normal rat spermatozoa. Unstained fresh preparation. $\times 450$.

Fig. 11. Spermatozoa from a rat injected with rhodium chloride intratesticularly. Note head and tail separation. Salts 16,16a and 18a exerted similar effects. Unstained fresh preparation. $\times 90$.

FIG. 12. Magnified view of a portion of Fig. 11 to show head and tail separation of spermatozoa. $\times 450$. 


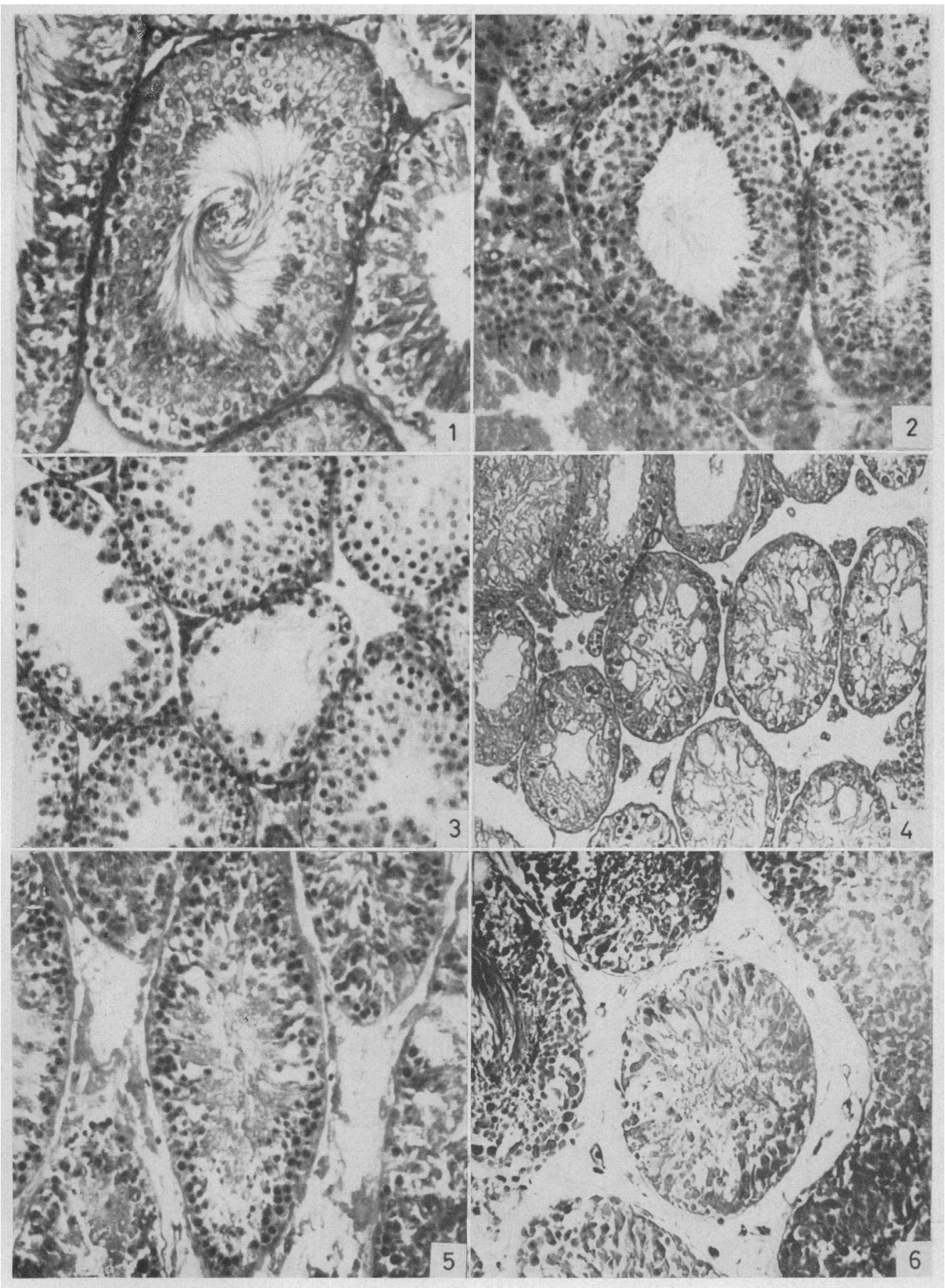

(Facing p. 28 ) 


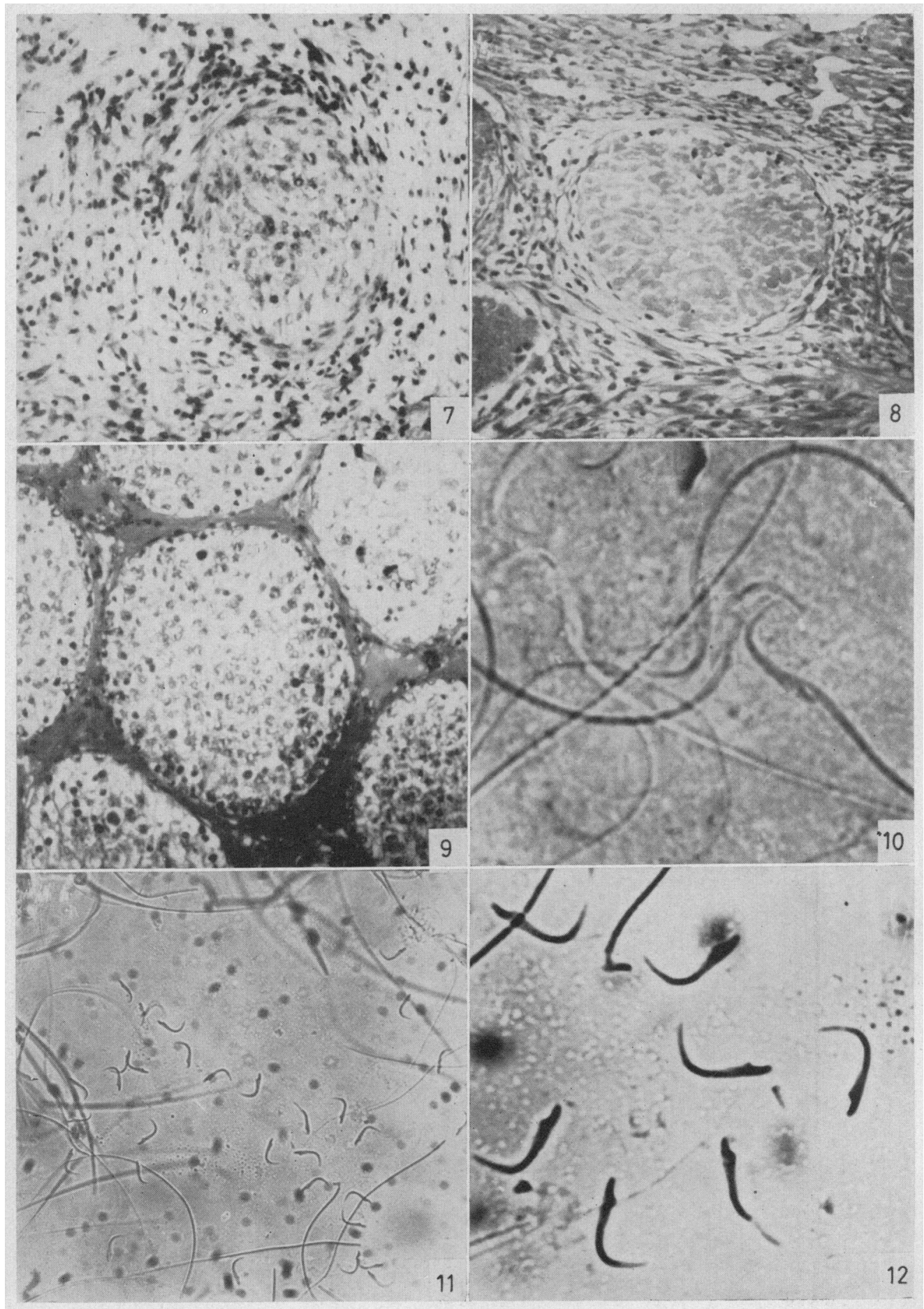

